\title{
The relationship between adipokines, body composition, and bone density in men with chronic obstructive pulmonary disease
}

This article was published in the following Dove Press journal:

International Journal of COPD

9 July 2009

Number of times this article has been viewed

\author{
Sheryl F Vondracek' \\ Norbert F Voelkel ${ }^{2}$ \\ Michael T McDermott ${ }^{3}$ \\ Connie Valdez' \\ 'Department of Clinical Pharmacy; \\ ${ }^{3}$ Department of Medicine, University \\ of Colorado Denver, Aurora, CO, \\ USA; ${ }^{2}$ Department of Internal \\ Medicine and Victoria Johnson \\ Center for Emphysema Research, \\ Virginia Commonwealth University, \\ Richmond, VA, USA
}

\begin{abstract}
Osteoporosis is common in patients with chronic obstructive pulmonary disease (COPD). Data regarding the relationship between adipokines and bone mineral density (BMD) in this population is lacking. The purpose of this pilot study was to determine associations between the adipokines tumor necrosis factor-alpha (TNF- $\alpha$ ), leptin, adiponectin and resistin, body composition, and BMD in men with severe COPD. This was a cross-sectional study of men with severe COPD who visited the University of Colorado Hospital COPD Center. Bone density and parameters of body composition were measured by dual-energy X-ray absorptiometry. Twenty-three men were included (mean age $=66$ years, mean percent predicted forced expiratory volume in one second $=32 \%$ ). On bivariate analysis, there was no association between TNF- $\alpha$ and BMD. Parameters of body composition and serum concentrations of leptin and adiponectin were significantly associated with total hip and spine bone density. However, with partial correlation analysis, total body mass was the only independent predictor of total hip BMD, explaining approximately $50 \%$ of the variability. Overall, 18 out of 23 men enrolled (78\%) had low bone density by T-score, and nine (39\%) were classified as having osteoporosis. The men with osteoporosis had lower parameters of body composition, lower mean serum leptin concentrations, and a greater impairment in measures of lung function compared to the men without osteoporosis. We conclude that the effect of adipokines on BMD does not appear to be independent of body mass. However, larger studies are needed to further evaluate the relationship between adipokines, body weight, and BMD in patients with COPD.

Keywords: bone mineral density, osteoporosis, TNF- $\alpha$, leptin, adiponectin, chronic obstructive pulmonary disease, adipokines
\end{abstract}

\section{Introduction}

Patients with chronic obstructive pulmonary disease (COPD) are at high risk for developing osteoporosis with a reported incidence ranging from $36 \%-60 \%{ }^{1-4}$ Osteoporosis-related fractures of the hip and spine increase pain and disability, reduce quality of life, and can increase the risk for death by $2-3$-fold. ${ }^{5,6}$ In addition to factors that increase the risk for osteoporosis in the general population (eg, family history), there are several factors specific to patients with COPD that increase their risk for bone loss and fractures. A long history of cigarette smoking is the primary cause for the development of COPD in up to $80 \%-90 \%$ of patients and smoking is considered an independent risk factor for the development of osteoporosis. ${ }^{7-11}$ Patients with COPD are frequently treated with systemic corticosteroids, which have been associated with significant and rapid increases in bone loss and fracture risk when used chronically. ${ }^{12-14}$ The increased risk for osteoporosis in patients with COPD cannot be completely
Correspondence: Sheryl F Vondracek Associate Professor, University of Colorado Denver, School of Pharmacy C238-LI5, I263I E, I7th Ave, Aurora, CO 80045, USA

Tel +l 3037242638

Fax + I 3037242627

Email sheryl.vondracek@ucdenver.edu 
explained by corticosteroid use as several cross-sectional studies have demonstrated low bone mineral density (BMD) and high fracture rates in patients with COPD not receiving systemic corticosteroids. ${ }^{1,3,15-18}$ Impaired lung function (as measured by forced expiratory volume in one second $\left[\mathrm{FEV}_{1}\right]$ ) has been shown to be an independent predictor of osteoporosis in several cross-sectional studies of patients with and without COPD. ${ }^{19-25}$ The extent of pulmonary emphysema has also been demonstrated to have a significant negative correlation with BMD. ${ }^{26}$ As the severity of COPD worsens, dyspnea can limit a patient's mobility. This may lead to significant disability, deconditioning, and lack of physical activity, which has been associated with bone loss and increased fracture risk. ${ }^{27}$

Low body weight and weight loss are well documented predictors of bone loss and independent predictors of increased fracture risk. ${ }^{28-31}$ Approximately $35 \%-60 \%$ of patients with moderate to severe COPD have a low body mass index (BMI) or evidence of weight loss. ${ }^{32}$ In several cross-sectional studies, a low BMI was the only factor independently correlated with osteoporosis risk in patients with COPD. ${ }^{3,15,17,33-36}$ Therefore, body weight appears to play an important role in osteoporosis risk in patients with COPD.

Patients with COPD have an increased risk for osteoporosis. While many underlying factors contribute to this process, they do not completely explain the increased risk. One area that deserves further investigation is the role of adipokines in the development osteoporosis in this population. Adipose tissue produces and releases substances called adipokines which include tumor necrosis factor-alpha (TNF- $\alpha$ ), leptin, adiponectin, and resistin. ${ }^{37}$ It has been hypothesized that the effect of body weight on BMD might be mediated through the effects of these adipokines on bone remodeling. ${ }^{38}$ Several studies have demonstrated associations between adipokines and BMD in various patient populations with conflicting results..$^{39-50}$ Studies of adipokines in patients with COPD are limited and to our knowledge, no published studies have evaluated the relationship between TNF- $\alpha$, leptin, adiponectin or resistin and BMD in patients with COPD. Therefore, the purpose of this pilot study was to evaluate the relationship between adipokines, body composition and BMD in men with severe, stable COPD.

\section{Materials and methods}

\section{Study objectives}

The primary objective of this study was to evaluate the relationship between TNF- $\alpha$ and its receptors tumor necrosis factor receptor (TNFR)-1 and TNFR-2 and total hip and lumbar spine BMD in men with severe COPD. The secondary objectives were (1) to evaluate the relationship between leptin, adiponectin, and resistin and total hip and lumbar spine BMD, (2) to evaluate the relationship between TNF- $\alpha$, TNFR-1, TNFR-2, leptin, adiponectin and resistin and body composition, and (3) to compare clinical characteristics, parameters of body composition, pulmonary function, and adipokine levels in men with severe COPD who have osteoporosis and osteopenia or normal bone density.

\section{Patients}

This was a cross-sectional pilot study. Patients meeting inclusion criteria were recruited from the University of Colorado Hospital COPD Center. The study was approved by the Colorado Multiple Institutional Review Board and informed consent was obtained from all participants.

Patients were included in the study if they were male, between the age of 45 to 89 years, had severe COPD defined as the ratio of $\mathrm{FEV}_{1}$ to forced vital capacity $(\mathrm{FVC})<0.70$ and $\mathrm{FEV}_{1}$ postbronchodilator $<50 \%$ predicted and their COPD had been clinically stable for the last two months. Clinically stable COPD was defined as no record of pulmonary infections, COPD exacerbations, or change in COPD-related medications within the last two months. Patients were excluded if they had a history of asthma or significant bronchodilator reversibility; diagnosis of systolic heart failure (left ventricular ejection fraction $<45 \%$ ); chronic kidney disease (defined as an estimated glomerular filtration rate $<60 \mathrm{ml} / \mathrm{min}$ for $>3$ months); current infection; human immunodeficiency virus; pulmonary infection within the last two months; significant liver impairment (defined by elevations in aminotransferases of $2 \times$ upper limit of normal); a history of collagen vascular, rheumatologic, neoplastic or thyroid disorders; untreated hypogonadism, or any underlying cause for metabolic bone disease; treatment with drugs known to alter bone metabolism including: bisphosphonates, teriparatide, or calcitonin; treatment with drugs known to alter TNF- $\alpha$ concentrations (eg, pentoxifylline, melatonin); and a history of continuous oral corticosteroid use (defined as continuous administration for three or more weeks) within the previous two years. A history of inhaled corticosteroid use or short bursts of oral corticosteroids for $<3$ weeks were permitted.

\section{Study visits}

Patients were required to attend two study visits. The first visit took place at the University of Colorado Hospital COPD Center where subjects underwent a brief interview, a urine 
sample was collected, and venous blood samples were drawn. The second visit took place at the University Of Colorado Clinical Nutrition Research Unit Energy Balance Lab where body composition and bone density were obtained using dual-energy X-ray absorptiometry (DXA).

\section{Data collection}

The following information was collected from the patient's medical record: age, race/ethnicity, average number of COPD exacerbations per year (based on data within the last two years), smoking history (current or past and pack-years), past medical history, current medications, oxygen use, most recent six-minute walk test data and full pulmonary function test results conducted during stable disease $\left(\mathrm{FEV}_{1}, \mathrm{FVC}\right.$, $\mathrm{FEV}_{1} / \mathrm{FVC}$ ratio, diffusion capacity of carbon monoxide [DLCO], residual volume [RV], total lung capacity [TLC], thoracic gas volume [TGV]).

All patients were interviewed by a study investigator at the first study visit regarding risk factors for osteoporosis including: family history of osteoporosis, calcium and vitamin D intake (daily supplements and dietary intake), and personal history of fracture. Data collected from the medical record was clarified with the patient during the interview (eg, past medical history, smoking history, current medications).

\section{Collection and analysis of blood samples}

Venous blood samples were collected into three serum separator tubes by the University of Colorado Hospital clinical laboratory phlebotomist. Due to the timing of the COPD clinic visits, patients were not required to fast prior to the blood draw. Two serum separator tubes were sent to the University of Colorado Hospital clinical laboratory for immediate analysis of total testosterone, estradiol, osteocalcin (biomarker for bone formation), and 25-hydroxyvitamin D (25-OHD). Total testosterone was measured by chemiluminescence using the Beckman-Coulter Access Immunoassay System (Fullerton, CA), reference range 200-850 ng/dL; 25-OHD was measured by chemiluminescence using Nichols Institute Diagnostic (San Juan Capistrano, CA), reference range $9-57 \mathrm{ng} / \mathrm{mL}$; estradiol was measured by chemiluminescence using the Beckman-Coulter Access Immunoassay System (Fullerton, CA), male reference range 20-75 pg/mL, and osteocalcin was measured by DiaSorin competitive radioimmunoassay (Stillwater, $\mathrm{MN}$ ), reference range $1.1-10.8 \mathrm{ng} / \mathrm{mL}$.

The other serum separator tubes were used for batch analysis of TNF- $\alpha$, TNFR-1, TNFR-2, leptin, adiponectin, and resistin. Within one hour of collection, the serum was separated from blood cells by centrifugation at $1,000 \times \mathrm{g}$ for 15 minutes. It was harvested with sterile transfer pipettes, aliquotted into $0.5 \mathrm{ml}$ serum tubes and immediately stored at $-80^{\circ} \mathrm{C}$. Serum TNF- $\alpha$, TNFR-1, TNFR-2, leptin, adiponectin, and resistin concentrations were measured in duplicate with enzyme-linked immunosorbent (ELISA) kits (Quantikine HS and Quantikine; R\&D Systems, Inc., Minneapolis, MN). The intra-assay and inter-assay coefficient of variations for these tests are as follows TNF- $\alpha=5.3 \%-8.8 \%$ and $10.8 \%-16.7 \%$, TNFR- $1=3.6 \%-5.0 \%$ and $3.7 \%-8.8 \%$, TNFR- $2=2.6 \%-4.8 \%$ and $3.5 \%-5.1 \%$, leptin $=3.0 \%-3.3 \%$ and $3.5 \%-5.4 \%$, adiponectin $=2.5 \%-4.7 \%$ and $5.8 \%-6.8 \%$, and resistin $=3.8 \%-5.3 \%$ and $7.8 \%-9.2 \%$, respectively.

\section{Measurement of urinary NTX}

Urinary N-telopeptide (NTX), an important biomarker for bone turnover, was obtained in all patients. On enrollment, all subjects were given a sterile specimen cup and instructed to collect a single second-morning void urine sample the day of the first study visit. Subjects were instructed to keep the urine sample refrigerated until the time of the study visit. This urine sample was sent to the University of Colorado Hospital clinical laboratory for determination of NTX, which was measured by ELISA (Ostex International Inc., Seattle, WA) and expressed as a ratio to urinary creatinine concentrations. Normal adult male reference range $=20-83 \mathrm{nmol} \mathrm{BCE} / \mathrm{mmol}$ creatinine.

\section{Measurement of BMD and body composition}

Whole body composition, and BMD of the lumbar spine (L1-4), total hip, femoral neck and total body were measured by DXA using the Hologic Delphi W densitometer (Hologic Corp, Waltham, MA). Subjects were scanned in light clothing while lying in the supine position. The precision of BMD measurements using this instrument was $<1.5 \%$ and the standard deviations for repeated measurements of fat free mass and fat mass was $0.5 \mathrm{~kg}$. Prior to the scan, height was measured to the nearest 0.5 centimeters using a wall-mounted stadiometer with the patient in their bare feet, and weight was measured to the nearest $0.1 \mathrm{~kg}$ with subjects barefoot and in light clothing. The weight in $\mathrm{kg}$ divided by height in meters $^{2}$ was used to calculate BMI.

\section{Statistical analysis}

Data are presented as means \pm standard deviations. P values less than 0.05 are considered statistically significant. 
Adiponectin, leptin, resistin, and total body mass were log-transformed to normalize distribution. Pearson's Correlation Test was performed to evaluate for potential relationships. For the secondary analyses, covariates were chosen based on a significant relationship with total hip BMD $(\mathrm{P}<0.05)$. Collinear variables were eliminated using a cluster analysis. Partial correlation analysis was performed on the selected covariates with total hip BMD as the dependent variable and adjusting for total body mass. Patients were divided into groups according to the presence or absence of osteoporosis based on T-score and history of low trauma fracture. Continuous variables were compared between patient groups using the Wilcoxon test. Nominal data were compared using Chi-square or Fischer's exact test. Pearson's correlation test was performed using GraphPad Prism 4 software (San Diego, CA). All other statistical analyses were performed using R Statistical Package, Version 2.4.1 (http://www.r-project.org).

\section{Results}

Twenty-five patients were enrolled in the study. Two patients were excluded. One patient died prior to completing the study and one patient was excluded after completing the study due to a reported history of childhood asthma, and pulmonary function testing that revealed significant reversibility and a normal diffusion capacity. Twenty-three patients are included in this analysis.

The general characteristics of the entire study population are presented in Table 1. All patients were Caucasian. The mean age was 66 (8.7) years and the mean $\mathrm{FEV}_{1}$ was $32 \%$ (11) of predicted. Approximately $80 \%$ of patients were on inhaled corticosteroids and chronic oxygen therapy. Based on DXA T-scores, $30 \%$ of patients had bone densities in the osteoporotic range and an additional $48 \%$ in the osteopenic range.

On bivariate analysis, there was no relationship between TNF- $\alpha$, TNFR-1, or TNFR-2 and total hip BMD or lumbar spine BMD (Table 2). There was also no significant correlation between TNF- $\alpha$, TNFR-1, or TNFR-2 and parameters of body composition (data not shown). There was a significant positive correlation with serum leptin concentrations, and a significant negative correlation with serum adiponectin concentrations and total hip and spine BMD (Table 2). However, after adjusting for total body mass, which had the strongest association $\left(\mathrm{r}^{2}=0.48\right)$; correlations been total hip and spine BMD and serum concentrations of leptin and adiponectin were no longer significant. There were no significant correlations between total hip and spine BMD and
Table I General characteristics of the study population

\begin{tabular}{|c|c|}
\hline Characteristic & $(n=23)$ \\
\hline Age (years) & $66(8.7)$ \\
\hline Caucasian, n (\%) & $23(100)$ \\
\hline Body mass index $\left(\mathrm{kg} / \mathrm{m}^{2}\right)$ & $26.4(6.9)$ \\
\hline $\mathrm{FEV}_{1}(\%$ of predicted) & $32(11)$ \\
\hline History of smoking, n (\%) & $23(100)$ \\
\hline Current, n (\%) & $5(22)$ \\
\hline Pack-years & $60.8(22.3)$ \\
\hline Home oxygen, $\mathrm{n}(\%)$ & $19(83)$ \\
\hline \multicolumn{2}{|l|}{ Pulmonary medications, $\mathrm{n}$ (\%) } \\
\hline Inhaled corticosteroid & $19(79)$ \\
\hline Long-acting inhaled $\mathrm{B}_{2}$-agonist & $13(57)$ \\
\hline Long-acting inhaled anticholinergic & II (43) \\
\hline Total hip BMD T-score & $-I . I \pm I . I$ \\
\hline Lumbar spine BMD T-score & $-1.2 \pm 1.2$ \\
\hline Normal, n (\%) ${ }^{a}$ & $5(22)$ \\
\hline Osteopenia, n (\%) & II (48) \\
\hline Osteoporosis, n (\%) & $7(30)$ \\
\hline
\end{tabular}

Notes: Values given as mean (SD) unless otherwise specified. aWorld Health Organization Criteria using dual-energy $\mathrm{x}$-ray absorptiometry BMD T-scores.

Abbreviations: $\mathrm{FEV}_{1}$, forced expiratory volume in one second; BMD, bone mineral density.

serum concentrations of testosterone, estradiol, osteocalcin, and 25-OHD or urinary NTX.

Selected bivariate correlations with serum leptin and adiponectin are summarized in Table 3. Serum leptin concentrations were significantly positively correlated with parameters of body composition and negatively correlated with urinary NTX, and lung volumes (Table 3 ). In contrast, serum adiponectin concentrations had a smaller, yet significant, negative correlation with parameters of body composition and demonstrated a significant negative correlation with serum concentrations of resistin, TNFR- 1 and TNFR-2. There was a significant inverse relationship between leptin and adiponectin.

Characteristics of the study population stratified according to osteoporosis status are summarized in Table 4. All body composition parameters were significantly lower in the patients with osteoporosis (Table 5). There was no significant difference between the groups with regards to total testosterone, estradiol, 25-OHD concentrations, and markers of bone turnover. Patients with osteoporosis had significantly lower mean \% predicted $\mathrm{FEV}_{1}(24.5$ vs $37 ; \mathrm{P}=0.003)$ and DLCO ( 29.4 vs $42.1 ; \mathrm{P}=0.036$ ) values and there was a trend towards higher lung volumes. Serum leptin was significant lower (3.8 vs $9.8 \mathrm{ng} / \mathrm{mL} ; \mathrm{P}=0.046$ ) and adiponectin concentrations 
Table 2 Selected bivariate correlations with total hip and spine bone mineral density

\begin{tabular}{|c|c|c|c|c|}
\hline \multirow[t]{2}{*}{ Parameter } & \multicolumn{2}{|c|}{ Total hip BMD } & \multicolumn{2}{|c|}{ Spine BMD } \\
\hline & $\mathbf{R}$ & $p$ & $\mathbf{R}$ & $p$ \\
\hline \multicolumn{5}{|l|}{ Adipokines } \\
\hline TNF- $\alpha(n g / m L)$ & 0.014 & 0.95 & -0.016 & 0.94 \\
\hline TNFR-I (pg/mL) & 0.216 & 0.32 & -0.028 & 0.90 \\
\hline TNFR-2 (ng/mL) & 0.233 & 0.28 & 0.073 & 0.74 \\
\hline Leptin (ng/mL) & 0.616 & $0.002^{\mathrm{a}}$ & 0.456 & 0.03 \\
\hline Adiponectin (ng/mL) & -0.531 & $0.009^{a}$ & -0.426 & 0.04 \\
\hline Resistin (ng/mL) & 0.225 & 0.30 & -0.194 & 0.38 \\
\hline \multicolumn{5}{|l|}{ Body composition } \\
\hline Body mass index $\left(\mathrm{kg} / \mathrm{m}^{2}\right)$ & 0.600 & 0.003 & 0.483 & 0.02 \\
\hline Total fat (kg) & 0.635 & 0.001 & 0.443 & 0.03 \\
\hline Total lean (kg) & 0.633 & 0.001 & 0.579 & 0.004 \\
\hline Total body mass (kg) & 0.690 & $0.0003^{a}$ & 0.564 & 0.005 \\
\hline \multicolumn{5}{|l|}{ Markers of bone turnover } \\
\hline Osteocalcin (ng/mL) & -0.161 & 0.46 & -0.40 & 0.06 \\
\hline Urinary NTX (nmol BCE/mmol creatinine) & -0.302 & 0.16 & -0.328 & 0.13 \\
\hline \multicolumn{5}{|l|}{ Hormones } \\
\hline Testosterone (ng/dL) & -0.265 & 0.57 & -0.104 & 0.64 \\
\hline Estradiol (pg/mL) & 0.184 & 0.40 & 0.293 & 0.17 \\
\hline $25-\mathrm{OHD}(\mathrm{ng} / \mathrm{mL})$ & -0.232 & 0.29 & -0.079 & 0.72 \\
\hline \multicolumn{5}{|l|}{ Lung function } \\
\hline $\mathrm{FEV}_{1} \% \mathrm{P}$ & 0.405 & 0.06 & 0.329 & 0.13 \\
\hline DCLO \% P & 0.354 & 0.11 & 0.111 & 0.62 \\
\hline TGV \% P & -0.541 & 0.009 & -0.342 & 0.12 \\
\hline TLC \% P & -0.555 & $0.007^{\mathrm{a}}$ & -0.360 & 0.10 \\
\hline $\mathrm{RV} \% \mathrm{P}$ & -0.490 & 0.02 & -0.359 & 0.10 \\
\hline
\end{tabular}

Notes: aNo correlations were seen between total hip BMD and TLC \% P, leptin, and adiponectin after adjustment for total body mass with partial correlation analysis. Abbreviations: BMD, bone mineral density;TNF, tumor necrosis factor;TNFR, tumor necrosis factor receptor; NTX, N-telopeptide; 25-OHD, 25-hydroxy vitamin D; FEV, \% $\mathrm{P}$, forced expiratory volume in one second percent predicted; DLCO \% P, diffusion capacity of carbon monoxide percent predicted; TGV \% P, thoracic gas volume percent predicted; TLC \% P, total lung capacity percent predicted; RV \% P, residual volume percent predicted.

trended higher $(8969.2 \mathrm{vs} 3333.2 \mathrm{ng} / \mathrm{mL} ; \mathrm{P}=0.07)$ in the osteoporosis group.

\section{Discussion}

Osteoporosis is common in men with severe COPD. In our study, $78 \%$ of the men enrolled had low bone density and nearly $40 \%$ were classified as having osteoporosis. Those patients with osteoporosis had worse lung disease as evidenced by lower mean \% predicted $\mathrm{FEV}_{1}$ and DLCO values compared to those without osteoporosis. In addition, all body composition parameters were significantly lower in this population, as were mean serum leptin concentrations. There was no difference in serum concentrations of TNF- $\alpha$ or its receptors. On bivariate analysis of the total study population, there was no association between TNF- $\alpha$ and BMD. Parameters of body composition, lung volumes, and serum leptin and adiponectin concentrations were significantly associated with total hip and spine BMD. However, consistent with previous studies, body mass was the only independent predictor of BMD at these sites. ${ }^{3,33,51}$ Approximately $50 \%$ of the variability in total hip BMD could be accounted for by the total body mass in this population.

The relationship between body weight and BMD is complex and not completely understood. Possible explanations for the protective bone effects of increased body weight include increased aromatization of androgens to estrogen in adipose tissue, mechanical loading, lower levels of sex hormone-binding globulin, and increased bone formation due to high circulating insulin levels. ${ }^{52}$ Adipose tissue produces and releases a variety of proinflammatory and antiinflammatory factors including TNF- $\alpha$, leptin, adiponectin, and resistin. ${ }^{37,53}$ It has been hypothesized that the effect of 
Table 3 Selected bivariate correlations with serum leptin and adiponectin

\begin{tabular}{|c|c|c|c|c|}
\hline \multirow[t]{2}{*}{ Parameter } & \multicolumn{2}{|l|}{ Leptin } & \multicolumn{2}{|c|}{ Adiponectin } \\
\hline & $\bar{R}$ & $p$ & $\overline{\mathbf{R}}$ & $p$ \\
\hline \multicolumn{5}{|l|}{ Adipokines } \\
\hline Leptin (ng/mL) & - & - & -0.648 & 0.0008 \\
\hline Adiponectin (ng/mL) & -0.648 & 0.0008 & - & - \\
\hline Resistin (ng/mL) & 0.268 & 0.22 & -0.417 & 0.048 \\
\hline TNF- $\alpha(\mathrm{ng} / \mathrm{mL})$ & 0.038 & 0.86 & -0.243 & 0.26 \\
\hline TNFR-I (pg/mL) & 0.266 & 0.22 & -0.552 & 0.006 \\
\hline TNFR-2 (ng/mL) & 0.298 & 0.17 & -0.557 & 0.006 \\
\hline \multicolumn{5}{|l|}{ Body composition } \\
\hline Body mass index $(\mathrm{kg} / \mathrm{m} 2)$ & 0.800 & $<0.0001$ & -0.658 & 0.0006 \\
\hline Total fat $(\mathrm{kg})$ & 0.836 & $<0.0001$ & -0.629 & 0.001 \\
\hline Total lean (kg) & 0.442 & 0.04 & -0.319 & 0.14 \\
\hline Total body mass (kg) & 0.7586 & $<0.0001$ & -0.601 & 0.002 \\
\hline \multicolumn{5}{|l|}{ Bone mineral density } \\
\hline Total body BMD $\left(\mathrm{g} / \mathrm{cm}^{2}\right)$ & 0.550 & 0.007 & -0.462 & 0.03 \\
\hline Total hip BMD $\left(\mathrm{g} / \mathrm{cm}^{2}\right)$ & 0.616 & 0.002 & -0.531 & 0.009 \\
\hline Lumbar spine BMD $\left(\mathrm{gm} / \mathrm{cm}^{2}\right)$ & 0.456 & 0.03 & -0.426 & 0.04 \\
\hline \multicolumn{5}{|l|}{ Markers of bone turnover } \\
\hline Urinary NTX (nmol BCE/mmol creatinine) & -0.702 & 0.0002 & 0.463 & 0.03 \\
\hline Osteocalcin (ng/mL) & 0.048 & 0.83 & -0.004 & 0.99 \\
\hline \multicolumn{5}{|l|}{ Lung function } \\
\hline $\mathrm{FEV}_{1} \% \mathrm{P}$ & 0.328 & 0.13 & -0.387 & 0.07 \\
\hline DCLO \% P & 0.264 & 0.23 & -0.266 & 0.23 \\
\hline TGV \% P & -0.620 & 0.002 & 0.457 & 0.03 \\
\hline TLC \% P & -0.561 & 0.007 & 0.444 & 0.04 \\
\hline $\mathrm{RV} \% \mathrm{P}$ & -0.552 & 0.008 & 0.357 & 0.10 \\
\hline
\end{tabular}

Abbreviations: BMD, bone mineral density; TNF, tumor necrosis factor; TNFR, tumor necrosis factor receptor; NTX, N-telopeptide; FEV $\%$ P, forced expiratory volume in one second percent predicted; DLCO \% P, diffusion capacity of carbon monoxide percent predicted; TGV \% P, thoracic gas volume percent predicted; TLC \% P, total lung capacity percent predicted; $\mathrm{RV} \% \mathrm{P}$, residual volume percent predicted.

body weight on BMD might be mediated through the effects of these adipokines on bone remodeling.

Tumor necrosis factor- $\alpha$ has been implicated as contributing to cachexia in various chronic disease populations and elevated levels of TNF- $\alpha$ have been demonstrated in patients with COPD who have a low body weight or reduced skeletal muscle. ${ }^{35,36,54-59} \mathrm{TNF}-\alpha$ is a potent stimulator of osteoclastic bone resorption and has been linked to bone loss in several inflammatory disease states such as rheumatoid arthritis, inflammatory bowel disease, and ankylosing spondylitis. ${ }^{32,60-63}$ It was postulated that elevated levels of TNF- $\alpha$ may contribute to the low body weight and low BMD in patients with COPD. However, in our study, there was no difference in serum concentrations of TNF- $\alpha$, or its receptors TNFR- 1 and TNFR- 2 between patients with or without osteoporosis and they did not significantly correlate with BMD or bone turnover markers.
Our results do not rule out the potential that the TNF system plays a role in cachexia and bone loss in patients with COPD. Evaluation of TNF- $\alpha$ at one time point may not be able to capture the long-term systemic inflammation picture. It is possible that increases in TNF- $\alpha$ during acute exacerbations contribute to bone loss and that levels are not significantly elevated during stable phases of the disease. ${ }^{64}$ Nearly $80 \%$ of our patients were on high-dose inhaled corticosteroids. It is unknown whether inhaled steroid use could have impacted the TNF results. Studies that demonstrate elevated levels of TNF- $\alpha$ in patients with COPD do not report the incidence of inhaled corticosteroid use by the study population.

The role of leptin in bone turnover and osteoporosis is not completely understood. In vitro data suggest that leptin stimulates bone formation possibly by acting on human marrow stromal cells to enhance osteoblast and inhibit adipocyte 
Table 4 Characteristics of patients with and without osteoporosis

\begin{tabular}{|c|c|c|}
\hline Characteristic & $\begin{array}{l}\text { Osteoporosis }^{a} \\
(n=9)\end{array}$ & $\begin{array}{l}\text { No osteoporosis } \\
(n=14)\end{array}$ \\
\hline Age (years) & $65.2(10.8)$ & $66.4(6.5)$ \\
\hline Body mass index $\left(\mathrm{kg} / \mathrm{m}^{2}\right)$ & $22.6(4.2)$ & $28.9(7.2)^{c}$ \\
\hline History of smoking, n (\%) & $9(100)$ & $14(100)$ \\
\hline Current, n (\%) & $2(22)$ & $3(2 I)$ \\
\hline Pack-years & $55(27.7)$ & $64.3(18.4)$ \\
\hline AECOPD (number/year) & I.3 (2.0) & $0.6(0.9)$ \\
\hline Home oxygen, n (\%) & $8(89)$ & II (79) \\
\hline \multicolumn{3}{|l|}{ Pulmonary medications, n (\%) } \\
\hline Inhaled corticosteroid & $6(67)$ & $12(86)$ \\
\hline Long-acting inhaled $\mathrm{B}_{2}$-agonist & $5(56)$ & $8(57)$ \\
\hline Long-acting inhaled anticholinergic & $4(44)$ & $6(43)$ \\
\hline \multicolumn{3}{|l|}{ Central DXA BMD T-scores } \\
\hline Total hip & $-1.97(0.56)$ & $-0.49(0.97)$ \\
\hline Lumbar spine & $-2.24(1.04)$ & $-0.54(0.73)$ \\
\hline
\end{tabular}

Notes: Values given as mean (SD) unless otherwise specified. ${ }^{\mathrm{a} B a s e d}$ on dual-energy X-ray absorptiometry T-score or a history of osteoporotic fracture; ${ }^{\mathrm{b} B a s e d}$ on dual-energy X-ray absorptiometry T-score; ${ }^{c} \mathrm{P}=0.014$

Abbreviations: AECOPD, acute exacerbation chronic obstructive pulmonary disease; BMD, bone mineral density; DXA, dual-energy X-ray absorptiometry.

differentiation. ${ }^{65,66}$ Leptin also inhibits osteoclastagenesis by decreasing the receptor activator of nuclear factor- $\mathrm{KB}$ (RANK) and its ligand (RANKL) and increasing the production of osteoprotegerin (OPG) ${ }^{66}{ }^{6}$ Therefore, reduced levels of leptin may result in both reduced bone formation and increased bone resorption. The effect of leptin on BMD may differ depending on the skeletal site. In a study of leptin-deficient mice, cortical thinning was observed, while trabecular volume was increased compared to control mice. ${ }^{67}$ In addition, adipocyte infiltration was seen in the femoral marrow, but not the vertebral marrow of the leptin-deficient mice. Therefore, leptin deficiency may have a greater effect on hip BMD compared to spine BMD. In our study, there was a stronger correlation between leptin and BMD at the total hip compared to the lumbar spine.

Leptin concentrations strongly correlate with BMI and body fat in patients with COPD..$^{64,68-70}$ Similar to the literature, a strong positive correlation between leptin and parameters of body composition was observed in our patients. Data regarding the relationship between serum or plasma leptin concentrations and bone turnover markers or BMD are conflicting. ${ }^{39,40,42-48}$ In a prospective study of 139 postmenopausal women, plasma leptin was positively correlated with $\mathrm{BMD}$ at the lumbar spine $(\mathrm{r}=0.233 ; \mathrm{P}<0.01)$, femoral neck $(\mathrm{r}=0.293 ; \mathrm{P}<0.001)$ and total body $(\mathrm{r}=0.177 ; \mathrm{P}<0.05) .{ }^{39}$ These associations remained significant after controlling for percent body fat, age, years since menopause and height. In a population-based longitudinal study of 302 elderly women and men, baseline plasma leptin concentrations were significantly associated with BMD at the lumbar spine $(\mathrm{r}=0.36$ and $0.27 ; \mathrm{P}<0.001)$ and femoral neck $(\mathrm{r}=0.35$ and 0.30; $\mathrm{P}<0.001)$, but not after controlling for BMI. ${ }^{43}$ In a longitudinal cohort study, serum leptin was associated with BMD at all sites in both older men and older women $(\mathrm{P}<0.01) .{ }^{45}$ However, after controlling for covariates such as age and BMI, the relationship was only significant in women. Similarly, in another cohort study, leptin significantly correlated with BMD after adjusting for lean mass and age at all sites, but only in the postmenopausal woman cohort $(\mathrm{r}=0.18-0.42 ; \mathrm{P}<0.05) .{ }^{47}$ There was no association between leptin and BMD in the male cohort. Only one study in men has demonstrated an association between leptin and BMD after controlling for body weight, but not after controlling for other bone-related factors. ${ }^{71}$

None of these studies evaluated patients with COPD. In our study of men with COPD, leptin was positively associated with BMD and negatively associated with urinary NTX indicating lower BMD and higher bone turnover with lower leptin levels. Similar to other studies, this relationship between leptin and BMD was not independent of body weight in our population. It has been suggested that the relationship between leptin and BMD is possibly mediated through the association of both variables with body mass and not the direct effect of leptin on bone cell numbers or function. ${ }^{43}$

Weight loss is a potent inducer of adiponectin synthesis. ${ }^{53}$ In one study, elevated plasma adiponectin correlated with 
Table 5 Comparison of patients with and without osteoporosis

\begin{tabular}{|c|c|c|c|}
\hline Parameter & $\begin{array}{l}\text { Osteoporosis }^{a} \\
(n=9)\end{array}$ & $\begin{array}{l}\text { No osteoporosis } \\
(n=14)\end{array}$ & $p$ \\
\hline \multicolumn{4}{|l|}{ Adipokines } \\
\hline Leptin (ng/ml) & $3.8(4.7)$ & $9.8(8.7)$ & 0.046 \\
\hline Adiponectin (ng/mL) & $8969.2(8008)$ & $3333.2(1788.8)$ & 0.069 \\
\hline Resistin (ng/mL) & $14.9(6.9)$ & |4.I (4.3) & 0.76 \\
\hline TNF- $\alpha(n g / m L)$ & $1.6(0.4)$ & $1.6(0.3)$ & 0.86 \\
\hline TNFR-I (ng/mL) & $1.2(0.5)$ & $1.2(0.4)$ & 0.99 \\
\hline TNFR-2 (ng/mL) & $2.6(1.0)$ & $3.0(1.1)$ & 0.41 \\
\hline \multicolumn{4}{|l|}{ Body composition } \\
\hline Total body fat $(\mathrm{kg})$ & I5.6 (5.9) & $28.2(13.5)$ & 0.007 \\
\hline Total body lean (kg) & $47.1(3.7)$ & $55.6(9.9)$ & 0.009 \\
\hline Total body mass (kg) & $64.8(4.9)$ & $86.4(22.4)$ & 0.008 \\
\hline \multicolumn{4}{|l|}{ Bone turnover markers } \\
\hline Urinary NTX (nmol BCE/mmol creatinine) & $38.4(17.8)$ & $27.9(\mid 5.9)$ & 0.18 \\
\hline Osteocalcin (ng/mL) & $5.3(2.9)$ & $3.8(2.7)$ & 0.28 \\
\hline \multicolumn{4}{|l|}{ Hormones } \\
\hline Testosterone (ng/dL) & $340.2(150.6)$ & $319.9(145.9)$ & 0.75 \\
\hline Estradiol $(\mathrm{pg} / \mathrm{mL})$ & $24.7(12)$ & $33.6(19.0)$ & 0.23 \\
\hline $25-\mathrm{OHD}(\mathrm{ng} / \mathrm{mL})$ & $28.8(15.7)$ & $23.9(9.1)$ & 0.42 \\
\hline \multicolumn{4}{|l|}{ Lung function } \\
\hline FEVI \% P & $24.5(7.9)$ & $37(10)$ & 0.003 \\
\hline TGV \% P & $210.3(45.1)$ & $173.2(4 \mid .5)$ & 0.08 \\
\hline $\mathrm{RV} \% \mathrm{P}$ & $258.5(80)$ & $194.2(68.7)$ & 0.08 \\
\hline TLC \% P & $|3| .5(2 \mid .8)$ & II $2.5(21.8)$ & 0.07 \\
\hline DLCO \% P & $29.4(10.2)$ & $42.1(16.2)$ & 0.036 \\
\hline
\end{tabular}

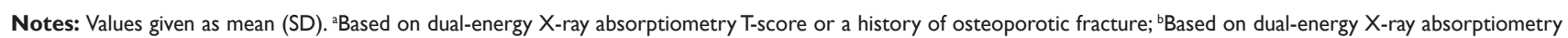
T-score.

Abbreviations: TNF, tumor necrosis factor; TNFR, tumor necrosis factor receptor; NTX, N-telopeptide; 25-OHD, 25-hydroxy vitamin D; FEV, \% P, forced expiratory volume in one second percent predicted; DLCO \% P, diffusion capacity of carbon monoxide percent predicted; TGV \% P, thoracic gas volume percent predicted; TLC \% P, total lung capacity percent predicted; RV \% P, residual volume percent predicted.

BMI, hyperinflation, and increased TNF- $\alpha$ levels in men with COPD. ${ }^{57}$ Bone mineral density was not evaluated in this study. Elevated levels of adiponectin may have a deleterious effect on bone through increasing RANKL and inhibiting the production of OPG, which would enhance bone resorption. ${ }^{72}$ Several studies have demonstrated a significant inverse relationship between adiponectin and BMD independent of body weight. ${ }^{49,50,73}$ In a large population-based cohort study, a doubling of serum adiponectin in postmenopausal women was associated with a mean percent decrease in BMD of $1.8 \%$ at all sites after controlling for covariate including BMI and central fat mass. ${ }^{49}$ In a cohort study of older men and women, adiponectin levels were negatively associated with BMD at all sites even after controlling for sex, age, height, fat mass, and leptin. ${ }^{74}$ Despite the correlation between adiponectin and $\mathrm{BMD}$, there was no association between adiponectin and fracture risk in a subgroup analysis of one of the male cohorts.
In our study, there was a trend towards higher adiponectin levels in patients with osteoporosis and there was a significant negative relationship between adiponectin and BMD and a significant positive relationship between adiponectin and urinary NTX. However, similar to leptin, this relationship was not independent of body mass.

Resistin is a pro-inflammatory adipokine, which stimulates synthesis of TNF and other cytokines through a nuclear factor- $\kappa \mathrm{B}$-dependent pathway. ${ }^{53}$ While its role in bone metabolism in unknown, one study demonstrated a significant inverse correlation between serum resistin and lumbar spine BMD after adjustment for age and BMI in men. ${ }^{42}$ There was no correlation between resistin and BMD in our study and there was no difference in resistin levels between the subjects with or without osteoporosis. Interestingly, resistin did significantly correlate with TNFR-1 $\left(r^{2}=0.803\right)$ and TNFR-2 $\left(r^{2}=0.514\right)$. 
There are several limitations to this study. The sample size was small limiting the power to properly control for confounding variables and determine true associations. Venous blood samples were not collected in a fasting state or at the exact same time of the day in each patient, which may have impacted the adipokine levels. While it is standard to collect such samples after an overnight fast, there are several studies that indicate leptin and adiponectin levels do not substantially change postprandially. ${ }^{75-80}$ Therefore, we believe that the timing of the samples do not significantly impact our results. In addition, our results were consistent with what was expected based on the literature. Pulmonary function testing was not prospectively performed as a part of this study. Results were obtained from the patient's medical record. While all pulmonary function tests results were performed at the $\mathrm{UCH}$ and during stable disease, some were obtained up to a year prior to enrollment into the study.

Our study demonstrated a high incidence of osteoporosis in men with severe COPD. Men with COPD and osteoporosis tended to have worse lung disease and significantly lower body mass and serum leptin concentrations compared to men with COPD, but without osteoporosis. Consistent with other studies, body weight was the only independent predictor of BMD in this population. This pilot study is important because it is the first study to evaluate the relationship between adipokines and BMD in patients with COPD. While these study results cannot refute or support the role of adipokines in the development of osteoporosis in men with COPD, it does bring into question whether the effect of body mass on BMD is mediated through the actions of adipokines on bone metabolism. Larger studies evaluating the potential role of adipokines in the development of osteoporosis are needed as well as research to better understand how low body weight contributes to low bone density in this population.

\section{Disclosure}

This study was supported by grants from Proctor and Gamble Pharmaceuticals, the University of Colorado Denver Department of Clinical Pharmacy and the University of Colorado Denver Energy Balance Lab of the Clinical Nutrition Research Center. The authors report no conflicts of interest in this work.

\section{References}

1. Jorgensen NR, Schwarz P, Holme I, Henriksen BM, Petersen LJ, Backer V. The prevalence of osteoporosis in patients with chronic obstructive pulmonary disease: a cross sectional study. Respir Med. 2007;101(1):177-185.

2. Franco CB, Paz-Filho G, Gomes PE, et al. Chronic obstructive pulmonary disease is associated with osteoporosis and low levels of vitamin D. Osteoporos Int. 2009;Mar 20. [Epub ahead of print].
3. Iqbal F, Michaelson J, Thaler L, Rubin J, Roman J, Nanes MS. Declining bone mass in men with chronic pulmonary disease: contribution of glucocorticoid treatment, body mass index, and gonadal function. Chest. 1999;116(6):1616-1624.

4. Yeh SS, Phanumas D, Hafner A, Schuster MW. Risk factors for osteoporosis in a subgroup of elderly men in a Veterans Administration nursing home. J Investig Med. 2002;50(6):452-457.

5. Center JR, Nguyen TV, Schneider D, Sambrook P, Eisman J. Mortality after all major types of osteoporotic fracture in men and women: an observational study. Lancet. 1999;353:878-882.

6. Schlaich C, Minne HW, Bruckner T, et al. Reduced pulmonary function in patients with spinal osteoporotic fractures. Osteoporos Int. 1998;8(3):261-267.

7. Ward KD, Klesges RC. A meta-analysis of the effects of cigarette smoking on bone mineral density. Calcif Tissue Int. 2001;68(5):259-270.

8. Hoidrup S, Prescott E, Sorensen TI, et al. Tobacco smoking and risk of hip fracture in men and women. Int J Epidemiol. 2000;29(2):253-259.

9. Kiel DP, Zhang Y, Hannan MT, Anderson JJ, Baron JA, Felson DT The effect of smoking at different life stages on bone mineral density in elderly men and women. Osteoporos Int. 1996;6(3):240-248.

10. Burger H, de Laet CE, van Daele PL, et al. Risk factors for increased bone loss in an elderly population: the Rotterdam Study. Am J Epidemiol. 1998;147(9):871-879.

11. Grisso JA, Kelsey JL, O’Brien LA, et al. Risk factors for hip fracture in men. Hip Fracture Study Group. Am J Epidemiol. 1997;145(9): 786-793.

12. Kanis JA, Johansson H, Oden A, et al. A meta-analysis of prior corticosteroid use and fracture risk. J Bone Miner Res. 2004;19(6):893-899.

13. Van Staa TP, Leufkens HG, Abenhaim L, Zhang B, Cooper C. Use of oral corticosteroids and risk of fractures. J Bone Miner Res. 2000;15(6):993-1000.

14. van Staa TP, Leufkens HG, Abenhaim L, Zhang B, Cooper C. Oral corticosteroids and fracture risk: relationship to daily and cumulative doses. Rheumatology (Oxford). 2000;39(12):1383-1389.

15. Katsura H, Kida K. A comparison of bone mineral density in elderly female patients with COPD and bronchial asthma. Chest. 2002;122(6):1949-1955.

16. McEvoy CE, Ensrud KE, Bender E, et al. Association between corticosteroid use and vertebral fractures in older men with chronic obstructive pulmonary disease. Am J Respir Crit Care Med. 1998; 157(3 Pt 1):704-709.

17. Dubois EF, Roder E, Dekhuijzen PN, Zwinderman AE, Schweitzer DH. Dual energy X-ray absorptiometry outcomes in male COPD patients after treatment with different glucocorticoid regimens. Chest. 2002; 121(5):1456-1463.

18. Johnell O, Pauwels R, Lofdahl CG, et al. Bone mineral density in patients with chronic obstructive pulmonary disease treated with budesonide Turbuhaler. Eur Respir J. 2002;19(6):1058-1063.

19. Bolton CE, Ionescu AA, Shiels KM, et al. Associated loss of fat-free mass and bone mineral density in chronic obstructive pulmonary disease. Am J Respir Crit Care Med. 2004;170(12):1286-1293.

20. Moayyeri A, Bingham SA, Luben RN, Wareham NJ, Khaw KT. Respiratory function as a marker of bone health and fracture risk in an older population. J Bone Miner Res. 2009;24(5):956-963.

21. Nuti R, Siviero P, Maggi S, et al. Vertebral fractures in patients with chronic obstructive pulmonary disease: the EOLO Study. Osteoporos Int. 2009;20(6):989-998.

22. Vrieze A, de Greef MH, Wijkstra PJ, Wempe JB. Low bone mineral density in COPD patients related to worse lung function, low weight and decreased fat-free mass. Osteoporos Int. 2007;18(9):1197-1202.

23. Kjensli A, Mowinckel P, Ryg MS, Falch JA. Low bone mineral density is related to severity of chronic obstructive pulmonary disease. Bone. 2007;40(2):493-497.

24. Lekamwasam S, Trivedi DP, Khaw KT. An association between respiratory function and bone mineral density in women from the general community: a cross sectional study. Osteoporos Int. 2002; 13(9):710-715. 
25. Sin DD, Man JP, Man SF. The risk of osteoporosis in Caucasian men and women with obstructive airways disease. Am J Med. 2003; 114(1):10-14

26. Ohara T, Hirai T, Muro S, et al. Relationship between pulmonary emphysema and osteoporosis assessed by CT in patients with COPD. Chest. 2008;134(6):1244-1249.

27. Henderson NK, White CP, Eisman JA. The roles of exercise and fall risk reduction in the prevention of osteoporosis. Endocrinol Metab Clin North Am. 1998;27(2):369-387.

28. Hannan MT, Felson DT, Dawson-Hughes B, et al. Risk factors for longitudinal bone loss in elderly men and women: the Framingham Osteoporosis Study. J Bone Miner Res. 2000;15(4):710-720.

29. Espallargues M, Sampietro-Colom L, Estrada MD, et al. Identifying bone-mass-related risk factors for fracture to guide bone densitometry measurements: a systematic review of the literature. Osteoporos Int. 2001;12(10):811-822.

30. Knoke JD, Barrett-Connor E. Weight loss: a determinant of hip bone loss in older men and women. The Rancho Bernardo Study. Am J Epidemiol. 2003;158(12):1132-1138.

31. Ensrud KE, Cauley J, Lipschutz R, Cummings SR. Weight change and fractures in older women. Study of Osteoporotic Fractures Research Group. Arch Intern Med. 1997;157(8):857-863.

32. Berry JK, Baum C. Reversal of chronic obstructive pulmonary diseaseassociated weight loss: are there pharmacological treatment options? Drugs. 2004;64(10):1041-1052.

33. Incalzi RA, Caradonna P, Ranieri P, et al. Correlates of osteoporosis in chronic obstructive pulmonary disease. Respir Med. 2000;94(11): 1079-1084.

34. Guerra S, Sherrill DL, Bobadilla A, Martinez FD, Barbee RA. The relation of body mass index to asthma, chronic bronchitis, and emphysema. Chest. 2002;122(4):1256-1263.

35. Pitsiou G, Kyriazis G, Hatzizisi O, Argyropoulou P, Mavrofridis E, Patakas D. Tumor necrosis factor-alpha serum levels, weight loss and tissue oxygenation in chronic obstructive pulmonary disease. Respir Med. 2002;96(8):594-598.

36. Eid AA, Ionescu AA, Nixon LS, et al. Inflammatory response and body composition in chronic obstructive pulmonary disease. Am J Respir Crit Care Med. 2001;164(8 Pt 1):1414-1418.

37. Rondinone CM. Adipocyte-derived hormones, cytokines, and mediators. Endocrine. 2006;29(1):81-90.

38. Rosen CJ, Klibanski A. Bone, fat, and body composition: evolving concepts in the pathogenesis of osteoporosis. Am J Med. 2009;122(5): 409-414.

39. Yamauchi M, Sugimoto T, Yamaguchi T, et al. Plasma leptin concentrations are associated with bone mineral density and the presence of vertebral fractures in postmenopausal women. Clin Endocrinol (Oxf). 2001;55(3):341-347.

40. Aguilar-Chavez EA, Gamez-Nava JI, Lopez-Olivo MA, et al. Circulating leptin and bone mineral density in rheumatoid arthritis. J Rheumatol. 2009;36(3):512-516.

41. Araneta MR, von Muhlen D, Barrett-Connor E. Gender differences in the association between adiponectin and bone mineral density, bone loss and fractures: The Rancho Bernardo Study. J Bone Miner Res. 2009; May 19. [Epub ahead of print].

42. Oh KW, Lee WY, Rhee EJ, et al. The relationship between serum resistin, leptin, adiponectin, ghrelin levels and bone mineral density in middle-aged men. Clin Endocrinol (Oxf). 2005;63(2):131-138.

43. Dennison EM, Syddall HE, Fall CH, et al. Plasma leptin concentration and change in bone density among elderly men and women: the Hertfordshire Cohort Study. Calcif Tissue Int. 2004;74(5): 401-406.

44. Yilmazi M, Keles I, Aydin G, et al. Plasma leptin concentrations in postmenopausal women with osteoporosis. Endocr Res. 2005;31(2): 133-138.

45. Weiss LA, Barrett-Connor E, von Muhlen D, Clark P. Leptin predicts BMD and bone resorption in older women but not older men: the Rancho Bernardo study. J Bone Miner Res. 2006;21(5):758-764.
46. Ruhl CE, Everhart JE. Relationship of serum leptin concentration with bone mineral density in the United States population. J Bone Miner Res. 2002;17(10):1896-1903.

47. Thomas T, Burguera B, Melton LJ, 3rd, et al. Role of serum leptin, insulin, and estrogen levels as potential mediators of the relationship between fat mass and bone mineral density in men versus women. Bone. 2001;29(2):114-120

48. Shaarawy M, Abassi AF, Hassan H, Salem ME. Relationship between serum leptin concentrations and bone mineral density as well as biochemical markers of bone turnover in women with postmenopausal osteoporosis. Fertil Steril. 2003;79(4):919-924.

49. Richards JB, Valdes AM, Burling K, Perks UC, Spector TD. Serum adiponectin and bone mineral density in women. J Clin Endocrinol Metab. 2007;92(4):1517-1523.

50. Jurimae J, Rembel K, Jurimae T, Rehand M. Adiponectin is associated with bone mineral density in perimenopausal women. Horm Metab Res. 2005;37(5):297-302.

51. Reid IR. Leptin deficiency - lessons in regional differences in the regulation of bone mass. Bone. 2004;34(3):369-371.

52. Barrett-Connor E, Kritz-Silverstein D. Does hyperinsulinemia preserve bone? Diabetes Care. 1996;19(12):1388-1392.

53. Tilg H, Moschen AR. Adipocytokines: mediators linking adipose tissue, inflammation and immunity. Nat Rev Immunol. 2006;6(10):772-783.

54. Argiles JM, Busquets S, Lopez-Soriano FJ. Cytokines in the pathogenesis of cancer cachexia. Curr Opin Clin Nutr Metab Care. 2003;6(4):401-406.

55. Yeh SS, Schuster MW. Geriatric cachexia: the role of cytokines. Am J Clin Nutr. 1999;70(2):183-197.

56. Debigare R, Cote CH, Maltais F. Peripheral muscle wasting in chronic obstructive pulmonary disease. Clinical relevance and mechanisms. Am J Respir Crit Care Med. 2001;164(9):1712-1717.

57. Tomoda K, Yoshikawa M, Itoh $\mathrm{T}$, et al. Elevated circulating plasma adiponectin in underweight patients with COPD. Chest. 2007;132(1): $135-140$.

58. Wouters EF. Chronic obstructive pulmonary disease. 5: systemic effects of COPD. Thorax. 2002;57(12):1067-1070.

59. Di Francia M, Barbier D, Mege JL, Orehek J. Tumor necrosis factoralpha levels and weight loss in chronic obstructive pulmonary disease. Am J Respir Crit Care Med. 1994;150(5 Pt 1):1453-1455.

60. Anker SD, Clark AL, Teixeira MM, Hellewell PG, Coats AJ. Loss of bone mineral in patients with cachexia due to chronic heart failure. Am J Cardiol. 1999;83(4):612-615, A10.

61. Ionescu AA, Nixon LS, Evans WD, et al. Bone density, body composition, and inflammatory status in cystic fibrosis. Am J Respir Crit Care Med. 2000;162(3 Pt 1):789-794.

62. Lange U, Teichmann J, Stracke H. Correlation between plasma TNF-alpha, IGF-1, biochemical markers of bone metabolism, markers of inflammation/disease activity, and clinical manifestations in ankylosing spondylitis. Eur J Med Res. 2000;5(12):507-511.

63. Romas E, Gillespie MT, Martin TJ. Involvement of receptor activator of NFkappaB ligand and tumor necrosis factor-alpha in bone destruction in rheumatoid arthritis. Bone. 2002;30(2):340-346.

64. Calikoglu M, Sahin G, Unlu A, et al. Leptin and TNF-alpha levels in patients with chronic obstructive pulmonary disease and their relationship to nutritional parameters. Respiration. 2004;71(1):45-50.

65. Thomas T, Gori F, Khosla S, Jensen MD, Burguera B, Riggs BL. Leptin acts on human marrow stromal cells to enhance differentiation to osteoblasts and to inhibit differentiation to adipocytes. Endocrinology. 1999;140(4):1630-1638.

66. Reid IR. Relationships between fat and bone. Osteoporos Int. 2008; 19(5):595-606.

67. Hamrick MW, Pennington C, Newton D, Xie D, Isales C. Leptin deficiency produces contrasting phenotypes in bones of the limb and spine. Bone. 2004;34(3):376-383.

68. Takabatake N, Nakamura H, Abe S, et al. Circulating leptin in patients with chronic obstructive pulmonary disease. Am J Respir Crit Care Med. 1999;159(4 Pt 1):1215-1219. 
69. Yang YM, Sun TY, Liu XM. The role of serum leptin and tumor necrosis factor-alpha in malnutrition of male chronic obstructive pulmonary disease patients. Chin Med J (Engl). 2006;119(8):628-633.

70. Schols AM, Creutzberg EC, Buurman WA, Campfield LA, Saris WH, Wouters EF. Plasma leptin is related to proinflammatory status and dietary intake in patients with chronic obstructive pulmonary disease. Am J Respir Crit Care Med. 1999;160(4):1220-1226.

71. Morberg CM, Tetens I, Black E, et al. Leptin and bone mineral density: a cross-sectional study in obese and nonobese men. J Clin Endocrinol Metab. 2003;88(12):5795-5800.

72. Luo XH, Guo LJ, Xie H, et al. Adiponectin stimulates RANKL and inhibits OPG expression in human osteoblasts through the MAPK signaling pathway. J Bone Miner Res. 2006;21(10):1648-1656.

73. Lenchik L, Register TC, Hsu FC, et al. Adiponectin as a novel determinant of bone mineral density and visceral fat. Bone. 2003;33(4): 646-651.

74. Michaelsson K, Lind L, Frystyk J, et al. Serum adiponectin in elderly men does not correlate with fracture risk. J Clin Endocrinol Metab. 2008;93(10):4041-4047.
75. Weigle DS, Duell PB, Connor WE, Steiner RA, Soules MR, Kuijper JL. Effect of fasting, refeeding, and dietary fat restriction on plasma leptin levels. J Clin Endocrinol Metab. 1997;82(2):561-565.

76. English PJ, Coughlin SR, Hayden K, Malik IA, Wilding JP. Plasma adiponectin increases postprandially in obese, but not in lean, subjects. Obes Res. 2003;11(7):839-844.

77. Considine RV, Sinha MK, Heiman ML, et al. Serum immunoreactiveleptin concentrations in normal-weight and obese humans. $N$ Engl J Med. 1996;334(5):292-295.

78. Romon M, Lebel P, Fruchart JC, Dallongeville J. Postprandial leptin response to carbohydrate and fat meals in obese women. $\mathrm{J} \mathrm{Am} \mathrm{Coll}$ Nutr. 2003;22(3):247-251.

79. Peake PW, Kriketos AD, Denyer GS, Campbell LV, Charlesworth JA The postprandial response of adiponectin to a high-fat meal in normal and insulin-resistant subjects. Int J Obes Relat Metab Disord. 2003; 27(6):657-662.

80. Karlsson FA, Engstrom BE, Lind L, Ohrvall M. No postprandial increase of plasma adiponectin in obese subjects. Obes Res. 2004; 12(6):1031-1032; author reply 2-4.

\section{Publish your work in this journal}

The International Journal of COPD is an international, peer-reviewed journal of therapeutics and pharmacology focusing on concise rapid reporting of clinical studies and reviews in COPD. Special focus is given to the pathophysiological processes underlying the disease, intervention programs, patient focused education, and self management protocols.

\section{Dovepress}

This journal is indexed on PubMed Central, MedLine and CAS. The manuscript management system is completely online and includes a very quick and fair peer-review system, which is all easy to use. Visit http://www.dovepress.com/testimonials.php to read real quotes from published authors.

Submit your manuscript here: http://www.dovepress.com/international-journal-of-copd-journal 